\title{
Taking the Framers Seriously
}

William Michael Treanor

Georgetown University Law Center, wtreanor@law.georgetown.edu

This paper can be downloaded free of charge from:

https://scholarship.law.georgetown.edu/facpub/1052

55 U. Chi. L. Rev. 1016-1040 (1988) (reviewing Walter Berns, Taking the Constitution Seriously (1987))

This open-access article is brought to you by the Georgetown Law Library. Posted with permission of the author. Follow this and additional works at: https://scholarship.law.georgetown.edu/facpub 


\title{
Taking the Framers Seriously
}

\author{
William Michael Treanor ${ }^{\dagger}$
}

Taking the Constitution Seriously. Walter Berns. Simon and Schuster, 1987. Pp. 287. $\$ 19.95$.

Walter Berns's Taking the Constitution Seriously ${ }^{1}$ champions a familiar thesis: the original meaning of the Constitution, Berns contends, is readily understandable and remains binding today. In addition, as with most other leading proponents of original intent, Berns's conception of the framers' intent accords with a modern conservative political agenda. Among the elements of his constitutional jurisprudence are opposition to judicial activism, a belief that the proper role of the national government is a very limited one, a strong commitment to the rights of property, and a conviction that the individual states can support the "moral education" (p. 222) of their citizens without running afoul of the first amendment.

Unlike most of the legal literature on original intent, however, the principal concern of Taking the Constitution Seriously is not with what the framers intended specific constitutional clauses to mean. Rather, Berns's principal concern is to reveal the political philosophy behind the Constitution, a philosophy which, he maintains, should inform our reading of the document. In delineating that philosophy, Berns relies on the constitutional text and on a handful of documents that either elucidate it, such as The Federalist Papers, or partake of the same world view as the Constitution, such as the Declaration of Independence.

Behind Berns's conception of the Constitution is a recognition of the fact that the world of the framers was a world in transition. In late eighteenth century America, pre-modern, pre-commercial society was ending. In its place, modern liberal (using the word in

† B.A. 1979, Yale University. A.M. 1982, Harvard University. J.D. 1985, Yale University. I would like to thank Morton Horwitz, Mike Koessel, Bill Nelson, Gene Sperling, Pat Wechsler, and Evan Wolfson for their help in the preparation of this review.

1 Walter Berns, Taking the Constitution Seriously (1987). All parenthetical page references in text and notes are to this work. 
its philosophical sense) commercial society was emerging. The framers, as depicted by Berns, were on the side of the winners, and their plan for the national government reflected their commitment to the new world. In writing the Constitution, the framers rejected the ideology dominant in pre-modern society, which held that the state's primary role was to define and inculcate virtue and that commercial life posed a threat to that virtue. In other words (to use a term that Berns does not use), the framers rejected classical republicanism.

Berns's framers opted instead for liberalism. Thus, the Constitution evidences a belief in the primacy of individual rights and in the importance of constraints on the national government; it embodies a commitment to the value of commerce and to the legitimacy of the pursuit of economic self-interest. At the same time, Berns contends that the Constitution did not represent a complete triumph for the forces of modernity. While it ensured that the national government would not be in the business of promoting and regulating morality, it did not so limit the individual state governments. The framers intentionally left the states free to engage in the older form of politics. In short, the national government was constructed on liberal principles, but the states could in important ways operate in accordance with republican principles.

Taking the Constitution Seriously is an imaginative, often engaging, but unconvincing book. As a work of constitutional philosophy, it is unsatisfying. On critical points, Berns's theory is inconsistent with his recommendations on how courts should act, and he fails to justify (or even fully acknowledge) those inconsistencies. But the more significant flaw in Berns's analysis is that, having implicitly recognized the transitional character of the world of the founding fathers, he fails to accord that fact appropriate significance. He assumes that our concerns and desires were the concerns and desires of the framers, that the framers had in some way come fully to terms with a modern world that they scarcely could have anticipated, and that their thought can be assimilated easily into our current policy debates. Those assumptions lead to a misreading of the framers that obscures the insights they have to offer.

This review will focus on three of the key historical points that Berns makes: his arguments that the Declaration of Independence is a Lockean document; that the Constitution encapsulates the political philosophy of the Declaration; and that the framers viewed the commercialization of society as a salutary development and were unambivalent champions of the right to property. Examination of these issues suggests that the ideological universe of the 
framers was far more complex than Berns indicates. While the revolutionary era witnessed a new concern with individual rights and a greater acceptance of the value of commerce, older notions of communitarianism, of public good, and of civic obligation remained powerful. In the revolutionary era and the early national period, the dominant ideological impulse was to attempt a synthesis that reflected both republican ideas and new realities, rather than simply to reject republicanism in favor of the brand of liberalism described by Berns. Thus, an attempt to honor the framers' intent does not lead to Berns's constitutional jurisprudence.

In addition, this review briefly examines another of Berns's historical claims: he maintains that the fourteenth amendment's due process clause was intended by its authors to refer only to procedural due process. This claim is important to Berns's overall argument because it is his contention that no constitutional development after ratification of the Constitution fundamentally altered the role of the federal courts with respect to the states. In support of his conclusion, Berns asserts that the framers of the fourteenth amendment intended that the provision should have a very limited effect and that this intent should be respected. Berns's contention that original intent (both of the framers of the Constitution and of the fourteenth amendment) can and must be outcome determinative raises issues beyond the scope of this review. But a look at pre-fourteenth amendment due process cases (cases to which recent scholars have paid little attention) offers an example of why textual interpretation is a far more complex matter than Berns indicates. Such examination also suggests one way in which an expansive reading of due process can be harmonized with framers' intent.

At the outset of Taking the Constitution Seriously, Berns describes the book as "an explanation of the Constitution by reference to the Declaration of Independence" (p. 11). The framers, Berns writes in explaining the relationship that he sees between the two documents, believed that a free government was the product of two compacts. As one manifestation of this view, he quotes from a letter that Madison wrote toward the end of his life:

Altho, the old idea of a compact between the Govt \& the people be justly exploded, the idea of a compact among those who are parties to a Govt is a fundamental principle of free Govt.

The original compact is the one implied or presumed, but nowhere reduced to writing, by which a people agree to form 
one society. The next is a compact, here for the first time reduced to writing, by which the people in their social state agree to a Govt over them (p. 24). ${ }^{2}$

The second compact in this country was the Constitution; the first was the agreement among the colonists in 1776 to sever their ties with England and form a new people. The Declaration of Independence was not itself the original compact, since the agreement is "nowhere reduced to writing." But Berns contends that the Declaration explained the original compact, articulating the reasons why Americans had decided to become a separate society and the principles of political society they believed most important.

While the notion of an original compact can be traced back to Hobbes, as well as Locke, Berns finds the Lockean influence on the Declaration to be more direct. The Declaration, he writes, was "inspired or informed by the political theory set forth by John Locke in the Letter [on Toleration] and the Second Treatise . . ." (p. 161). Because they embraced Locke and his natural rights philosophy, "the Americans of 1776 asserted their rights as men, not as Englishmen; they appealed not to the laws of the realm but to the laws of nature and of nature's God" (p. 31).

The key to understanding the principles of 1776 and of the Declaration (which Berns assumes are the same) thus becomes the question of what are natural rights, or, to use the language of the Declaration, what are unalienable rights. The Declaration provides an obvious source of guidance. It states that "among these [unalienable rights] are life, liberty and the pursuit of happiness." But the starting points for Berns's analysis is not the Declaration's text or a historical inquiry into what the framers thought natural rights to be. Rather, he starts from the premise that there are in fact determinable rights "possessed by everybody irrespective of nationality, color, faith, gender, or ethnic affiliation" (p. 28). They are universal because they are grounded in human nature (p. 28).

Taking the Constitution Seriously does not attempt to enumerate those rights completely, but it does provide a partial list of rights, all of which, Berns finds, had been previously recognized by Locke. "[T] he most basic of human rights," according to Berns, "[is] the right to consent to government, or the right to govern oneself" (p. 224). Liberty of conscience is also an unalienable right

${ }^{2}$ Quoting letter from James Madison to Nicholas P. Trist (February 15, 1830), in Gaillard Hunt, ed., 9 The Writings of James Madison 355 (1910).

${ }^{3}$ Declaration of Independence para. 3 (1776). 
(pp. 160-61). A third unalienable right (and a right that plays a critical role in Berns's jurisprudence) is the right to property. Why are such rights fundamental? Berns quotes with approval Justice William Paterson's 1795 decision in the circuit court case of Van Horne's Lessee v. Dorrance:

It is evident, that the right of acquiring and possessing property, and having it protected, is one of the natural, inherent, and unalienable rights of man. Men have a sense of property: Property is necessary to their subsistence, and correspondent to their natural wants and desires; its security was one of the objects, that induced them to unite in society. No man would become a member of a community, in which he could not enjoy the fruits of his honest labour and industry. The preservation of property then is a primary object of the social compact (pp. 225-26). ${ }^{4}$

Berns maintains that the commitment to natural rights evidenced by the Declaration also informed the Constitution. Revolutionary era Americans had been schooled in natural rights philosophy and accepted its teachings, and the Constitution, like the Declaration, reflected this consensus. "[B]ecause there was a general agreement that these rights were indeed fundamental, we the people were able to institute a government designed to secure them" (p. 225). The principles of the Declaration thus became the principles of government: "[The] Constitution did what the Declaration of Independence says must be done . . . : it instituted a government that secures human rights" (p. 121).

The Constitution has succeeded in securing human rights, Berns argues, primarily because it is animated by the belief that "government is supposed to leave us alone" (p. 149). The whole structure of the Constitution-its system of checks and balances, the establishment of an independent judiciary, its "ENLARGEMENT of the ORBIT" (p. 131) of governance to reflect a multiplicity of competing interests, and its system of representation designed to put some "distance . . . between the people and their representatives" (p. 144) - was intended to restrain the powers of government. According to Berns, the Constitution thus promotes liberty in a very direct fashion by limiting governmental power.

The framers also believed that the Constitution would pro-

+Quoting 2 Dall. 304, 309 (Pa. 1795). The original text uses the term "inalienable rights," but Berns's quotation substitutes the term "unalienable rights."

s Quoting Federalist 9, in Clinton Rossiter, ed., The Federalist Papers 71, 73 (1961). 
mote liberty in an important indirect way. They expected that the Constitution's limitations on governmental power would serve to protect the property right. When the property right is secured, people devote themselves to a life of commerce. They pursue private happiness, not public happiness, and this shift is beneficial. When people devote their lives to the public arena, they seek ascendancy for themselves or their political or religious causes, and this ascendancy can be achieved only at the expense of individual freedom. When they seek profit, they leave others alone. Berns writes:

By taking government out of the business of promoting morals and virtue, to use Rousseau's terms, they [the Framers] expected material gratification, or comfortable preservation, to emerge as the primary object of men's passions. In the past, governments had in one way or another attempted to suppress these passions, but the commercial republic would be built on them. The authors of The Federalist had learned from Montesquieu ... that commerce cures destructive prejudices, that it "softens barbaric morals," that it causes men to lose their taste for personal glory or conquest or desire for salvation, or any of the other things giving rise to destructive factions. It makes men "soft," but it makes constitutional government possible (pp. 177-78) (citation omitted).

Pre-modern thinkers had treated commerce as a source of corruption. In contrast, the framers enthusiastically championed commerce and the right to property-not because self-interest was a good in itself, but because its encouragement advanced the cause of liberty-and they devised a constitutional system in which individual pursuit of self-interest served as a bulwark against the abuse of state power. The Constitution realized what Berns describes as Locke's goal: "[T] he Leviathan . . . is transformed into the modern liberal state" (p. 172).

Thus, Berns pictures the framers as Lockean liberals, individuals committed to limited government, who believed the primary purpose of government to be the protection of individual rights. At the same time, he argues that their system of government was not purely liberal. Partly because the framers did not rigorously apply their political philosophy to the states and partly because the AntiFederalists wished to preserve state power, the Constitution did not take the states "out of the business of promoting morals and virtue." Berns writes, "[A]lthough the Framers (including all the lawyers among them) knew that their principles forbade the use of 
the laws directly to generate virtuous habits, they did not regard it as improper for the laws, and in practice this meant the laws of the states, to support the private institutions in which these habits had been generated and were to be generated" (p. 220). Because "the Framers expected the states to provide the sort of civic or moral education required of citizens in a republican regime," (p. 222) recent Supreme Court opinions holding that the state governments "must be neutral not merely between religions but between religion and irreligion . . . [are] not at all what the First Amendment meant to the men who added it to the Constitution" (p. 222).

Berns contends that the framers' vision of a liberal national government and non-liberal state governments is one that must still be respected. The Bill of Rights did not alter that vision, he argues, since its limitations were intended to apply only to the national government (pp. 124-29). ${ }^{8}$

Moreover, the fourteenth amendment was not inconsistent with this aspect of the framers' plans. The privileges or immunities clause allowed Congress to enumerate the privileges or immunities of national citizenship. Congress, however, initially failed to make a serious effort to exercise its powers under this clause, and the Supreme Court's decision in the Slaughterhouse Cases ${ }^{7}$ effectively stripped Congress of the powers that it could rightfully exercise under the clause (pp. 210-11). "Read literally" (and a literal reading is the methodology that Berns believes those with due respect for framers' intent are required to use), the due process and equal protection clauses should have had a very limited effect (p. 212). Berns writes, "Only by distortion of their terms could either of these clauses be made a measure of the constitutionality of state legislation" (p. 212). Due process merely requires state courts to follow accepted processes of law. Substantive due process decisions are not sanctioned by the clause, Berns contends, since substantive due process has "nothing whatever to do with the process of law" (p. 213). Similarly, equal protection merely means that the state executive cannot discriminate in the enforcement of laws: "Governors and sheriffs and the rest were now, for the first time, under a national constitutional obligation to provide the protection of the laws to any person within the jurisdiction of their states or counties" (p. 212). The clause was not intended to have any broader

\footnotetext{
B This is particularly the case, Berns argues, since Madison's proposal for an amendment prohibiting the states from infringing on various freedoms, including freedom of conscience, was rejected by the Senate (p. 168).

783 U.S. (16 Wall.) 36 (1872).
} 
meaning.

Berns also contends that the courts cannot "update" the framers' vision of the constitutional system. The author devotes a chapter to criticisms of judicial activism (pp. 192-231). He singles out Justice William Brennan's comment that "[ $t]$ he genius of the Constitution rests not in any static meaning it might have had in a world that is dead and gone, but in the adaptability of its great principles to cope with current problems and current needs" (pp. 206-07). ${ }^{\mathbf{B}}$ Berns contends that such statements indicate an illegitimate preference for the policy judgments of an unelected judiciary over the decisions embedded in the Constitution, which "is an act of the people in their constituting capacity" (p. 237). Moreover, Berns argues that since the constitutional convention decided not to establish a council of revision, in which members of the judiciary in combination with the executive would have had veto power over legislation, the framers clearly intended to deny the judiciary any role in policy making. He concludes that the judiciary should simply focus on the constitutional text and original intent. The resultant judicial role is a highly constrained one. Berns's comments about the impropriety of judicial "amendment" of the Constitution is indicative of his general view of the Constitution, properly understood: "[T] so obscure as to defy a search for its true meaning" (p. 240).

Taken together, the various elements of Berns's analysis combine to form a conservative constitutional agenda: a limited role for the federal government; a strong degree of concern for property rights; opposition to judicial activism and to expansive definitions of natural rights; a belief in the constitutionality of state activities designed to inculcate virtue. ${ }^{\cdot}$ The way in which he grounds this

${ }^{8}$ Quoting William Brennan, Jr., The Constitution of the United States: Contemporary Ratification, paper presented at Georgetown University, October 12, 1985, 7. The paper is reproduced in 27 So.Tex.L.Rev. 433 (1986).

"In his conclusion Berns writes:

[T]o speak of a conservative agenda is almost a contradiction, an oxymoron. Conservatives certainly cannot simply take stands opposite to those taken by liberals. They cannot, for example, adopt a program favoring primogeniture, laws of entail, titles of nobility, a social class structure, an established church, drawing and quartering, or any other traditional (but cruel and unusual) form of punishment. These causes are denied to conservatives by the Constitution; or better, the Framers of the Constitution deprived Americans of much, if not all, of a traditional conservative agenda . . . The only appropriate agenda for conservatives is to defend the liberal Constitution--if nec essary, to defend it from liberals--because by that Constitutional rights are secured (pp. 240-41).

Here, Berns is playing with the terms conservative and liberal. His vision of the Constitution is not conservative by eighteenth century standards. At the same time, it unquestion- 
agenda in framers' intent is creative. Berns could not have defended his constitutional jurisprudence by focusing exclusively on the text of any one document or the writings of any one thinker. The Constitution is not on its face a natural rights document. The Bill of Rights is arguably a natural rights document, but Berns minimizes its importance; one suspects this treatment is due in part to the Bill of Rights' open-ended language, which invites the kind of judicial activism that Berns opposes. "[A]n explanation of the Constitution by reference to the Declaration" allows a reading of natural rights into the Constitution without the need to rely on the Bill of Rights. At the same time, the language of the Declaration-in particular the statement that "all men are created equal, [and] that they are endowed by their Creator with certain unalienable rights"--also seems open-ended. But Berns limits the reach of this language by reading the Declaration as a Lockean document and by indicating that the Declaration and the Constitution share the same fundamental concerns. Thus, both Locke's and the Constitution's concerns for the protection of property are read into the Declaration, even though the Declaration does not mention the right of property as an unalienable right.

Another problem in grounding Bern's constitutional jurisprudence in the world view of the framers is that state inculcation of virtue comports neither with the liberal philosophy that he contends is behind the Declaration nor the liberal philosophy that he finds behind the Constitution. Berns resolves this problem as well through synthesis: he concludes that state promotion of religion is legitimate, not because the framers' ideology sanctioned it, but because the Constitution does not make the framers' ideology binding on the state governments.

Berns's explanation of his constitutional philosophy does not adequately respond to a number of questions that his approach obviously suggests. For example, the interpretive methodology he uses in explaining the Constitution is inconsistent with a denunciation of judicial activism. In other words, Berns's enterprise in this book is to ascertain at a relatively high level of generality the values implicit in the Constitution and then to urge that those values be applied today. This approach is an odd one for an individual who claims that constitutional interpretation should focus on text and pursue a very narrow search for original meaning; it is, however, quite similar to the approach employed by judges who 
"adapt" the Constitution. Berns never focuses on why he believes his use of this interpretive methodology yields a proper understanding of the Constitution, whereas judicial use of it is tantamount to deciding cases by personal whim.

Berns also fails to provide a coherent analysis when, in his discussion of the right to privacy, he confronts a tension between his proclaimed rights commitment and the evident conservative bias of his jurisprudence. The right to privacy would appear to be the quintessential human right for Berns, since he defines human rights as rights grounded in human nature. Moreover, it would appear to be a fundamental right in a government founded on the principle that the individual should be let alone by the government. "Constitutional government," Berns writes, "leaves men alone to the extent that it can; it certainly does not meddle in their private lives, and it gives an extensive definition to what is properly private" (pp. 154-55). Nonetheless, Berns rejects the idea that the Constitution guarantees a right to privacy. Moreover, he is particularly critical of Justice Blackmun's championing of such a right in his dissent in Bowers v. Hardwick. ${ }^{10}$

That dissent asserts that the case, which involved the constitutionality of Georgia's anti-sodomy law, implicates the right to be let alone. Berns responds that the right involved is the right to engage in private, consensual sexual activity. This is not a right, Berns indicates, because it is not generally accepted: "Strictly speaking, our rights may have their foundation in nature or in a duly enacted statute, but for their security they depend ultimately on the support not only of the public official but of public opinion" (p. 227). This additional requirement--that as a practical matter rights must be grounded in public support-is completely inconsistent with Berns's earlier position that rights can be determined from abstract reasoning about human nature. His criticism of Blackmun's dissent is similarly inconsistent with his earlier claims about constitutional government not "meddl[ing] in [people's] private lives." (p. 154-55). Berns, however, never addresses these obvious tensions.

Another issue that Berns fails to confront adequately arises from his intimations that Brown v. Board of Education ${ }^{11}$ was correctly decided, although on the wrong grounds (p. 216). As noted previously, Berns's definition of equal protection is extremely narrow-" $[\mathrm{g}]$ overnors and sheriffs and the rest were . . . under a na-

10 478 U.S. 186 (1986).

I1 347 U.S. 483 (1954). 
tional constitutional obligation to provide the protection of the laws to any person within the jurisdiction of their states or counties" (p. 212) - and, in discussing that clause, Berns indicated that it could not provide a basis for invalidating state legislation because it was addressed more to state executives than state legislators. Nonetheless, when he discusses Brown and the Court's decision to hold segregation unconstitutional, Berns writes:

The black school children were surely being denied a privilege that ought to have been enjoyed by all citizens, but, as even the most venerable opponents of racial discrimination have admitted, the Court did not make it evident that they were being denied the equal protection of the laws. The Court might have meant that for a state to separate by race is to treat races differently and therefore-although the conclusion is by no means obvious-unequally; but what it said was that "separate educational facilities are inherently unequal," a logical absurdity ... (p. 216). ${ }^{12}$

The idea of equal protection employed by Berns to suggest that Brown's result might have been reached on other grounds is much broader than the definition he had offered earlier. As with his discussion of Hardwick, Berns here departs from his original view without explanation or elaboration.

These jurisprudential inconsistencies and incoherencies do not, however, strike at the heart of the book. Berns's announced project is to explain what the framers intended. Confronting the book on its own terms requires historical inquiry into the world view of the framers and the political leaders of the early republic, the world view which Berns asserts should govern our understanding of the Constitution. The discussion that follows-which focuses on the ideology behind the Declaration, the relationship between the Declaration and the Constitution, and the framers' attitudes towards commerce and property - suggests that Berns's historical account is substantially inaccurate: it suppresses the enduring importance of non-liberal values and it fails to acknowledge the ideological diversity among the founders and the ideological change that took place within the revolutionary era.

As has been noted, Berns contends that the Declaration is a Lockean document. The position that the document is Lockean is certainly one with wide support in the historical literature. For example, in The Declaration of Independence, for over a half a cen-

12 Citing Brown, 347 U.S. at 495. 
tury the most influential work on the ideology of the Declaration, Carl Becker argued that "Jefferson copied Locke."13 But to assert that Jefferson followed Locke is not to say that he recognized an absolute property right.

It is arguable whether Locke recognized such a right. The standard formulation of Lockeian unalienable rights has come to be (and was in Jefferson's day) "life, liberty and property."14 At the same time, Locke recognized two limitations on man's capacity to acquire property: no one can take more than he can use, ${ }^{15}$ and there must be "enough, and as good left in common for others."16 Whether Locke believed that the introduction of civil law permitted the transcendence of these limits and justified unlimited acquisition of property is a matter of dispute among scholars, and it can plausibly be argued that Locke did not accept the transcendence of these limits. ${ }^{17}$

For Jefferson, at least, the proviso of "enough, and as good left in common for others" was clearly one that persisted in the civil state and that served to limit the property right. In this country, that proviso did not limit acquisition. As historian Stanley Katz has written, " $[\mathrm{F}]$ or Jefferson, America was the perfect environment for the operation of the Lockean theory of property shorn of its limitations, for in America the endless abundance of land and the inexhaustible continent rendered it unthinkable that either mere accumulation or unavailability could deprive each man of his due share of the natural stock of plenty." 18 Yet while Jefferson did not challenge the legitimacy of individual acquisitions during his political career in this country, he did act in accordance with the other implication of the proviso and consistently sought to bring about a broad distribution of property in society. For example, one of his

${ }^{13}$ Carl Becker, The Declaration of Independence 79 (1958).

i4 Garry Wills, Inventing America 229 (1979). As Wills notes, Locke generally used the word "estate" or "fortune" rather than "property," in conjunction with "life" and "liberty." See, e.g., John Locke, Treatise on Civil Government, in Treatise on Civil Government and A Letter Concerning Toleration 91, para. 137 (Charles L. Sherman ed. 1937)("Treatise")(men enter into society in order to "preserve their lives, liberties and fortunes"); id. at 82, para. 123 (men enter into society for the "mutual preservation of their lives, liberties and estates").

${ }^{16}$ Locke, Treatise on Civil Government at 21, para. 31.

${ }^{18}$ Id. at 19 , para. 27.

${ }_{17}$ Compare C.B. MacPherson, The Political Theory of Possessive Individualism 203, 211 (1962) (civil law justifies unlimited appropriation) with James Tully, A Discourse on Property 152-54, 165 (1980) (satisfaction of the proviso is a precondition of exclusive possession).

${ }^{18}$ Stanley N. Katz, Thomas Jefferson and the Right to Property in Revolutionary America, 19 J.L. \& Econ. 467, 475 (1976). 
proposed drafts of Virginia's constitution provided that everyone who had never owned fifty acres of land should be allotted that amount of property. A similar concern is reflected in Jefferson's Northwest Ordinance of 1787 and in his decision to make the Louisiana Purchase of $1803 .{ }^{18}$ Moreover, during his ambassadorship to France, when Jefferson confronted a situation in which there was not "enough, and as good left in common for others," he concluded that the system of property holdings "violate[d] natural right."20 He wrote in a letter home to James Madison:

Whenever there is in any country, uncultivated lands and unemployed poor, it is clear that the laws of property have been so far extended as to violate natural right. The earth is given as a common stock for man to labour and live on. If, for the encouragement of industry we allow it to be appropriated, we must take care that other employment be furnished to those excluded from the appropriation. If we do not the fundamental right to labour the earth returns to the unemployed. It is too soon yet in our country to say that every man who cannot find employment but who can find uncultivated land, shall be at liberty to cultivate it, paying a moderate rent. But it is not too soon to provide by every possible means that as few as possible shall be without a little portion of land. The small landowners are the most precious part of a state. ${ }^{21}$

None of the above is offered to suggest that Jefferson was bent on a program of economic redistribution. He clearly was not. But it does explain how he could be a Lockean-in the sense of holding that the end of government is to secure individual liberty-without being committed to an absolute property right (assuming that such a commitment is in fact Lockean). For Jefferson, the property right was not one of the unalienable rights. It was conditioned on the satisfaction of the requirement that there be "enough, and as good left in common." This understanding of Jefferson accords with the Declaration's proclamation of the right to "Life, Liberty and the pursuit of Happiness," rather than "Life, Liberty and Property."

In addition, there is a non-Lockean reading of the Declaration that also accords with the substitution of "pursuit of Happiness"

${ }^{18}$ Id. at $470-73$.

${ }^{20}$ Letter from Thomas Jefferson to James Madison (Oct. 28, 1785), in 8 Thomas Jefferson, The Papers of Thomas Jefferson 681, 682 (Julian P. Boyd ed. 1953).

${ }^{21}$ Id. 
for "Property." In Inventing America, Garry Wills contends that the Declaration reflected the ideas of the Scottish Enlightenment, rather than Locke. In developing this thesis, Wills notes that Jefferson had been trained in this school of thought by his teachers, whereas there is no parallel evidence of Jefferson's pre-1776 exposure to Locke's Second Treatise. Moreover, linguistic similarities exist between the writings of the Scottish Enlightenment thinker Frances Hutcheson and the Declaration. ${ }^{22}$ Berns seems to regard Wills's book as posing the principal threat to his own interpretation of the Declaration, and devotes his appendix to a critique of Wills's argument that the Constitution, rather than the Declaration, brought this nation into being (pp. 242-51). Berns also convincingly argues that the linguistic similarities between the Declaration and Locke's Second Treatise indicate that Jefferson was familiar with the work (pp. 247-48). ${ }^{23}$ But he never tries to rebut Wills's contention that the dominant influence on Jefferson was Scottish Enlightenment thought.

The significance of such an influence for interpretion of the Declaration is two-fold. First, in Scottish Enlightenment thought the property right is not an unalienable right. This school of thought is communitarian, and community interests are seen as limiting the right to property. ${ }^{24}$ To the extent that Wills is right, then, the property right was not inalienable for Jefferson.

Second, rights in the Scottish Enlightenment school do not consist, as they do in Locke's thinking, of a power that an individual can assert over-against the state. ${ }^{25}$ Rather, according to Wills, "[r]ight arises in, and because of, society; it is a power over others so long as benevolence or innocence are directing the powers. The test is public good." ${ }^{26}$ Thus, Frances Hutcheson offered the following definition of right:

Whenever it appears to us that a faculty of doing, demanding, or possessing anything, universally allowed in certain circumstances, would in the whole tend to the general good, we say that any person in such circumstances has a right to do, possess, or demand that thing. And according as this tendency to

22 See, e.g., Wills, Inventing America at 167-92, 229-39 (cited in note 14).

${ }^{23}$ Thus, Berns writes: 'The Declaration speaks of a 'long train of abuses,' for example, a phrase taken word for word from section 225 of the Treatise, and of "mankind [being] more disposed to suffer," which, in section 230 of the Treatise reads, "the people, who are more disposed to suffer'" (pp. 247-48).

24 Wills, Inventing America at 217, 229-39 (cited in note 14).

25 Id. at 213.

${ }^{28}$ Id. at 216. 
the public good is greater or lesser, the right in question is greater or less. ${ }^{27}$

The critical freedom is thus not freedom from, but freedom to. To put it another way, rights concern what the individual can do, as opposed to what the state cannot do.

If one assumes (as Berns does not) that courts have a special role to play in protecting and defining rights, and if one also accepts that Jefferson embraced the non-liberal notion that the individual's participation in the polity is a critically important aspect of the pursuit of happiness, ${ }^{28}$ the importance of this alternative rights theory in terms of the jurisprudential significance of the Declaration is immense. Judicial elaboration of the Scottish Enlightenment notion of rights would then involve judicial action designed to ensure that the individual was equipped to enter fully into the life of the polity. Significantly, although essentially unnoticed, some early state court cases embody such a rights notion.

The most striking example is Trustees of the University of North Carolina v. Foy and Bishop, ${ }^{29}$ in which the North Carolina Supreme Court held unconstitutional an act of the legislature repealing an earlier grant of all escheated lands to the state university. The court based its holding on two grounds. First, it held that the second statute violated the law of the land provision of the state constitution because no individual or organization could be deprived of liberties or properties "until the judiciary of the country in the usual and common form, pronounce them guilty of such acts, as will, in law, amount to a forfeiture of their rights or a dissolution of their body." ${ }^{30}$ This ground for decision led Professor Edward Corwin to proclaim Foy the first substantive due process case. $^{31}$

More interesting for our purposes, however, is the other basis for the holding, the court's determination that the second statute ran afoul of the provision of the state constitution establishing a state university. The court justified its holding here by a series of rhetorical questions:

27 Id., quoting Francis Hutcheson, An Inquiry into the Original of our Ideas of Beauty and Virtue (1725).

28 See Lance Banning, Jeffersonian Ideology Revisited, 43 Wm. \& Mary Q. 3, 18-19 (1986).

28 5 N.C. (1 Mur.) 53 (1805).

30 Id. at 79 .

31 Edward S. Corwin, The Doctrine of Due Process of Law Before the Civil War, 24 Harv.L.Rev. 366, 380-83 (1911). 
Is then, this last act authorised by the constitution, or does it destroy a right which that instrument gave to the people, a right highly esteemed in all civilized nations, that of educating their youth at a moderate expense? a right of acquiring knowledge and good morals, which have always been deemed most conducive to the happiness and prosperity of the people? ?2 $^{32}$

This second holding was clearly not compelled by the constitutional text. The relevant provision merely provided that there be a state university, not that it be funded in a certain way. The court apparently saw its role as one of ensuring that the preconditions of civic life were satisfied. Foy and Wills suggest, then, that the Declaration was part of an ongoing American tradition, one that stressed freedom to, as well as freedom from. ${ }^{33}$ Under this conception, rights include that which the individual needs to participate in the life of the polity.

Ultimately, it is probably wrong to attempt to reduce the Declaration to either a Scottish Enlightenment document or a Lockean document. Both readings of the document are coherent and both arguments for influence plausible. Moreover, it seems likely that at the time of the writing of the Declaration Jefferson had never faced a situation in which the fundamental tensions between the two philosophies had to be resolved. It also seems unlikely that in a political document Jefferson would opt for philosophical rigor over broad appeal. Thus, the Declaration probably reflects an intentional ambiguity. As Hannah Arendt has written, "[T] he Declaration of Independence . . . still intends us to hear the term "pursuit of happiness' in its two-fold meaning: private welfare as well as the right to public happiness, the pursuit of well-being as well as being a 'participator in public affairs.' "34 Neither interpretation, however, accords with Berns's reading of the Declaration. Both readings indicate that communitarianism played a critical role in Jeffersonian thought; Berns's does not. While Berns's constitutional jurisprudence turns on what the Declaration means, the document does not mean what he says it means. It does not embody

${ }^{32} 5$ N.C. at $75-6$.

${ }^{33}$ Scottish Enlightenment thought was not the only philosophy with some currency in America of this period that stressed freedom to. Although not primarily a rights philosophy, classical republicanism also conceptualized rights in this non-liberal way. See Banning, 43 Wm. \& Mary Q. at $18-19$ (cited in note 28 ).

34 Hannah Arendt, On Revolution 129 (1963); see also Banning, 43 Wm. \& Mary Q. at 18 (cited in note 28) (discussing Arendt's insight in terms of current historiographical debate of Jeffersonian ideology). 
the brand of liberalism he ascribes to it.

Moreover, the idea that the Declaration should provide the basis for constitutional jurisprudence is itself problematic. Implicit in much of Berns's analysis is the assumption that the nation's political leaders shared a common ideology and that the revolutionary era did not witness significant ideological change. Admittedly, he contends that the framers were liberals who, in the Constitution, allowed non-liberal politics to persist at the state level. $\mathrm{He}$ thus acknowledges that a liberal world view was not monolithic. But at the same time his analysis is predicated on the idea that, with respect to governance of the nation, the major political figures shared certain values at all relevant times. This assumption underlies Berns's claim to offer "an explanation of the Constitution by reference to the Declaration of Independence." But, contrary to Berns's contention, the Constitution is not a translation of the Declaration's natural rights concerns into principles of governance, and that fact underscores both the diversity in and the changing nature of revolutionary era political thought.

Certain differences between the two documents are obvious. The Declaration is a rhetorically powerful statement that justifies revolution; the Constitution is a legal document that creates a government. Addressing a "candid world," the Declaration appeals to "the laws of nature and of nature's god;" the only higher power that the Constitution explicitly recognizes is that of "We the People." The differences between the Declaration and the Constitution are not, however, simply ones of audience or function. If, in fact, the Constitution were meant to embody the Declaration's principles, it would seem likely that appeals to the Declaration would have been frequent in the debate over ratification. But the Declaration did not play a significant role in those debates. ${ }^{35}$ For example, it is quoted only once in The Federalist Papers. Moreover, the quoted language does not concern equality or unalienable rights. Rather, the Declaration is appealed to for the proposition that the people have a right "to abolish or alter their governments as to them shall seem most likely to effect their safety and happiness." ${ }^{36}$

According to the dominant view of the American Revolution among historians, the ideas that played the most significant role in causing the Revolution were derived from classical republicanism and English opposition thought. These schools of thought stressed that public virtue was the prerequisite for and the proper end of

36 Wills, Inventing America at 324 (cited in note 14).

${ }^{36}$ Federalist 40, in The Federalist Papers at 247, 253 (cited in note 5). 
good government, praised self sacrifice and deplored luxury, and maintained that the aggressive nature of governmental power constantly endangered public virtue. Influenced by these ideas, Americans in the 1770s saw eighteenth century British society as hopelessly corrupt and, consequently, viewed the attempts of the British ministry in the 1760 s and 1770 s to expand control over the colonies as a direct threat to American virtue. Americans broke with England because they came to believe that they faced a simple choice: American independence or American corruption. ${ }^{37}$

At the time independence was declared, individual liberties were not a central concern to most revolutionaries. As Gordon Wood has written, "[I]ndividual rights, even the most basic civil liberties that we consider so crucial, possessed little of their modern theoretical relevance when set against the will of the people."38 Accompanying this lack of emphasis on individual rights was a devotion to legislatures as the voice of the people. In combination, these two views led the first state constitutions to place almost all governmental power in the hands of state legislatures and allow them to act with few checks. ${ }^{39}$

The Constitution reflects a significantly different set of concerns and beliefs. The post-independence experience of self-governance-an experience marked by interest group conflict both in government and in society and by frequent legislative actions that aided one segment of society at the expense of others ${ }^{40}$ - convinced many of the framers to devote increased attention to limitations on the power of the majority and to protections for individual freedom. As Madison wrote in Federalist 51, "It is of great importance in a republic not only to guard the society against the oppression of its rulers, but to guard one part of the society against the injustice of the other part." ${ }^{11}$ The Constitution, because it constrained the power of state governments while permitting the national gov-

37 For works that played the most significant role in the development of this interpretation, see Bernard Bailyn, The Ideological Origins of the American Revolution (1967); J.G.A. Pocock, The Machiavellian Moment (1975); Gordon S. Wood, The Creation of the American Republic (1969). For recent historiographical works on the subject of republicanism, see Joyce Appleby, Republicanism in Old and New Contexts, 43 Wm. \& Mary Q. 20 (1986); Banning, 43 Wm. \& Mary Q. (cited in note 28); Robert E. Shalhope, Republicanism and Early American Historiography, 39 Wm. \& Mary Q. 334 (1982).

${ }_{38}$ Wood, Creation of the American Republic at 63.

39 See id. at 162-73.

${ }^{40}$ See Allan Nevins, The American States During and After the Revolution 507, 569-72 (1924) (discussing confiscation of loyalist property and legislative attempts to aid debtors through the issuance of paper money and the passage of stay laws).

${ }^{41}$ Federalist 51, in the Federalist Papers at $320,323$. 
ernment only limited powers subject to elaborate checks and balances, was intended to limit majoritarian excesses. Hamilton declared, "[T]he Constitution is itself, in every rational sense, and to every useful purpose, A BILL OF RIGHTS." 42

The Declaration does not fit easily into the story of ideological transformation just described. Its concern is with the threat to rights, not virtue. The Declaration would thus seem to state better the principles of 1787 than the principles of 1776 . While there is an obvious irony to this, it accords with the perceived significance of the document. In the 1770 s and 80 s, the Declaration was generally treated as important because it declared American independence, not because of the way in which it justified that independence. Only later did the Declaration come to seem important as a statement of political philosophy. ${ }^{43}$

At the same time, the Declaration's rights philosophy is not the rights philosophy behind the Constitution. The progressive historians, for example, believed that the adoption of the Constitution was a counterrevolution undoing much of the work of the Revolution, and argued that the Declaration's spirit is primarily concerned with the rights of man while the Constitution's spirit is more practically concerned with the rights of property. ${ }^{44}$ While the progressive argument goes too far-the Constitution is concerned with the rights of man as well as the rights of property-it catches an essential truth. For Madison and other framers, events of the revolutionary era had led to a heightened concern for the protection of property rights. As Madison wrote Jefferson:

The necessity of . . . guarding the rights of property was for obvious reasons unattended to in the commencement of the Revolution ..... In the existing state of American population, \& American property the two classes of rights were so little discriminated that a provision for the rights of persons was supposed to include of itself those of property, and it was natural to infer from the tendency of republican laws, that these interests would be more and more identified. Experience and investigation have however produced more correct ideas on this subject. ${ }^{45}$

42 Federalist 84 , in id. at $510,515$.

43 Wills, Inventing America at 324 (cited in note 14).

4 See, e.g., Richard Hofstadter, The Progressive Historians 192-93 (1970).

45 James Madison, Observations on the "Draught of a Constitution for Virginia," in Robert A. Rutland, Charles F. Hobson, et. al., eds., 11 Papers of James Madison 287 (1977). 
As Federalist 10 suggests, the constitutional scheme of checks and balances reflects, in part, a concern to protect the right to property in a society where "the most common and durable source of factions has been the verious and unequal distribution of property."46 As previously suggested, the Declaration does not reflect the same concerns for the rights of property-a difference attributable partly to Jefferson's authorship and partly to its genesis in a period when self sacrifice, rather than economic interest, was stressed.

Thus, the Declaration and the Constitution both reflect a fundamental concern for human rights, but it is the latter document that has a special concern for property rights. In view of Berns's constitutional jurisprudence, this is ironic. By reading that Declaration into the Constitution, Berns transforms the Constitution, which does not explicitly appeal to natural rights, into a natural rights document. But that reading cannot introduce a natural right to property into the Constitution, since the Constitution is more concerned with the property rights than the Declaration. Berns's concern for the property right would have been better served by ignoring the Declaration, rather than by installing it in a central place in constitutional jurisprudence. At the same time, the differences between the Declaration and the Constitution and the ideological change that occurred during the revolutionary era highlight that the men who Berns refers to as our "statesmen-teachers" (p. 241) were not all of the same school. As a result, no ideological group today can legitimately claim a monopoly on appeals to the founders.

For reasons already discussed, Berns is on more solid grounds in asserting that the right to property and the importance of commerce played a critical role in the thought of the people who drafted and ratified the Constitution. But he takes this point too far when he makes the framers into champions of laissez-faire economics and the virtue of self-interest. Republicanism-with its communitarianism and its stress on self-sacrifice and the importance of participation in the life of the polity-may not have been the dominant influence on economic thought at the time of ratification, but it continued to affect the discourse. Certainly at the time of ratification, there were many who accepted a laissez-faire economic policy and others who stressed self-interest as opposed to

${ }^{46}$ Federalist 10, in The Federalist Papers at 77, 79 (cited in note 5). See also id. at 78 ("The diversity in the faculties of men, from which the rights of property originate, is not less an insuperable obstacle to a uniformity of interests. The protection of these faculties is the first object of government."). 
classical virtue. But relatively few accepted the entire package.

This point is illustrated by contrasting the Jeffersonian and Hamiltonian economic stances, the two dominant stances in the early republic. Hamilton believed that government should operate realistically and try to harness economic self-interest, rather than vainly attempt to inculcate virtue. ${ }^{47}$ For example, he wrote:

We may preach till we are tired of the theme, the necessity of disinterestedness in republics, without making a single proselyte. The virtuous declaimer will neither persuade himself nor any other person to be content with a double mess of porridge, instead of a reasonable stipend for his services. We might as soon reconcile ourselves to the Spartan community of goods and wives, to their iron coin, their long beards, or their black broth. There is a total dissimulation in the circumstances, as well as the manners, of society among us . . . ${ }^{48}$

At the same time, it should be noted that, to the extent that Hamilton had come to terms with the benefits that might flow from pursuit of self-interest and the inappropriateness of governmental encouragement of virtue, his was so much a minority position that it was not always politically wise to acknowledge it. The line that Hamilton penned for Washington's Farewell Address-“Tis substantially true, that virtue or morality is a necessary spring of popular government. The rule indeed extends with more or less force to every species of Free Government"-hardly accords with Berns's description of uniform liberalism among the founders. ${ }^{49}$

While Hamilton and his adherents embraced self-interest, however, they did not embrace laissez-faire capitalism. The Hamiltonian economic program-which involved, among other things, a funded debt and the creation of a national bank-was interventionist and can be traced back to non-liberal notions that the state had an obligation to promote the general well-being. It certainly did not accord with the belief that "government is supposed to leave us alone" (p. 149).

The Jeffersonian economic program was, in contrast, largely laissez-faire and thus, in one sense, more liberal than the Hamiltonian program. Moreover, Jeffersonians were not opposed

${ }^{47}$ See Gerald Stourzh, Alexander Hamilton and the Idea of Republican Government 73 (1970); Katz, 19 J.L. \& Econ. at $485-87$ (cited in note 18).

${ }^{48}$ Katz, 19 J.L. \& Econ. at 485, quoting Alexander Hamilton, The Continentalist No. VI, in 3 The Papers of Alexander Hamilton 99, 103 (Harold C. Syrett ed. 1962).

${ }^{4 \theta}$ Stourzh, Alexander Hamilton and the Idea of Republican Government at 74 (quoting Washington's final manuscript of his Farewell Address) (cited in note 47). 
to commerce, and it is at least arguable that "[f]or the Jeffersonians the economy offered an escape from the predicaments implicit in traditional ways of looking at social order." time, Jeffersonians were far from unabashed champions of self-interest. As historian Lance Banning has written:

The Jeffersonians ... were still uncomfortable with the thought that uninhibited pursuit of market opportunities would automatically result in public happiness and harmony .... They held that individual improvement ought to be restrained by residual regard for others, that private satisfactions must sometimes give way to public duties. And they suspected that this commitment to community would be endangered if commerce and manufacturing, which they accepted as the proper narrow top of the pyramid of economic enterprise, should become too heavy for the pyramid's broad and equal agricultural base. ${ }^{51}$

The competing visions of Jeffersonians and Hamiltonians thus indicate that the framers were far from unabashed champions of the pursuit of purely private interests in a market free from government interference. While not hostile to commerce and property, the framers were far short of nineteenth century economic liberalism. In different ways, they rejected central tenets of the philosophy Berns ascribes to them.

The final historical issue that merits discussion has a bearing not on whether Berns's description of the ideology of the founders is accurate, but on his interpretive methodology. As noted, Berns states that the fourteenth amendment's due process clause-given a "literal reading" (p. 212)-simply obligates state courts to comply with accepted processes of law. This position comports with Berns's general position that the meaning of any constitutional clause is that which its framers intended and that that meaning is either clear from the text or that it can easily be determined with certainty by reference to contemporaneous documents. The prefourteenth amendment due process case law illustrates the weakness of this position.

so Appleby, $43 \mathrm{Wm}$. \& Mary Q. at 32 (cited in note 37 ).

s. Banning, $43 \mathrm{Wm}$. \& Mary Q. at 17 (cited in note 28). Banning's position has been criticized by Joyce Appleby, who has stressed the purely liberal elements of Jeffersonian republicanism. At the same time, Appleby, unlike Berns, has stressed the difference between Jeffersonian liberalism and nineteenth century liberalism with respect to notions of a common good transcending individual interests and the desirability of the unrestrained pursuit of economic self-interest. See Appleby, $43 \mathrm{Wm}$. \& Mary Q. at 33 (cited in note 37). 
Before passage of the fourteenth amendment, there was a body of case law interpreting due process clauses (or analogous law of the land clauses) to encompass what we today think of as substantive due process. Most notably, the Dred $S \cot { }^{62}$ decision invoked what we would today consider substantive due process. The Court there held, "[A]n act of Congress which deprives a citizen of the United States of his liberty or property, merely because he came himself or brought his property into a particular Territory of the United States, and who had committed no offense against the laws, could hardly be dignified with the name of due process of law." ${ }^{63}$ Moreover, a number of antebellum state court cases employed substantive due process to overturn state legislation. ${ }^{54}$ One example, University of North Carolina U. Foy, has already been discussed. Another leading example, this one from the eve of the Civil War, is Wynehamer $v$. State of New York, ${ }^{55}$ in which the New York Court of Appeals overturned a state statute that permitted the destruction of intoxicating liquors. The court held such destruction impermissible, even when accompanied "by the forms which belong to 'due process of law.' "\$66

As William Nelson has pointed out, there is no conclusive evidence as to whether the draftsmen of $\S 1$ of the fourteenth amendment had such cases in mind and meant to incorporate substantive due process into the amendment. ${ }^{87}$ Two lessons can, however, be drawn from those cases. First, Berns's suggestion that the clause as originally drafted necessarily meant only that courts had to comply with accepted processes of law is wrong. The search for the clause's meaning is not resolved by an examination of the "literal" meaning of the words used since the framers could plausibly have had in mind at least two meanings. More broadly, this limited case law suggests that, regardless of what the framers of the Constitution thought about judicial methodology, the framers of the fourteenth amendment had reason to know that judges read indeterminate clauses broadly, rather than searching for fixed, narrow meanings. That background understanding can fairly be held to have informed their use of indeterminate clauses when they wrote the fourteenth amendment. Use of the phrase "due process" arguably

${ }^{32}$ Dred Scott v. Sandford, 60 U.S. (19 How.) 393 (1857).

${ }^{33}$ 58. Id. at 450. See also Don E. Fehrenbacher, Slavery, Law and Politics 206 (1981) (quoted language was an "emphatic assertion of the principle of "substantive due process" ").

${ }^{34}$ See Corwin, 24 Harv.L.Rev. at 460 (cited in note 31).

3313 N.Y. 378 (1856).

${ }^{56}$ Id. at 420 .

${ }^{57}$ William Nelson, The Fourteenth Amendment chap. III (forthcoming). 
invited judicial activism.

Of course, arguments to the contrary can be made, but my point here is not to contend for one or another reading of the due process clause. It is, rather, to offer one example of why original intent is elusive in a way that Berns, in a book about original intent, never acknowledges.

Taking the Constitution Seriously seeks to make two uses of the ideology of the framers. It is an attempt by Berns to lay claim to the moral mantle of the founders. In the introduction to the book, he writes of historians who have minimized the importance of the Declaration in American history, "[T] hey know, with the Bible, that 'in the beginning was the word,' and they do not want America's word to be the word spoken in the Declaration" (p. 17). $\mathrm{He}$ adds, "It is probably true that all nations are affected in one way of another by the manner of their beginnings. . . . . What is true of Canada-or of Mexico, France, Britain and the others-is even truer of America. More than being affected by its beginning, this country is characterized by it" (p. 18). Berns believes that the way in which people conceive of their nation and its mission reflects, in part, their sense of how and why that nation came into being, and he therefore struggles to show that liberalism is the one and only word that brought forth this country: it is the word of the Declaration, which is the word of the Constitution, which is the word of the founders. Taking the Constitution Seriously also represents an attempt to use the ideology of the framers (as Berns conceptualizes it) to support a particular view of what the Constitution should mean. The framers' liberalism, Berns maintains, informed the Constitution they drafted and ratified. Proper respect for original intent requires that the liberalism inform modern constitutional interpretation.

Understanding the worldview of the framers is not, however, the simple matter that Berns suggests. The writings of the framers reflect a host of tensions. The framers felt the importance of enhancing both individual freedom and the common good. By and large, they thought both religious freedom and moral education of critical importance. They feared self-interest and esteemed selfsacrifice even as they moved toward greater acceptance of the world of commerce. While they differed among themselves as to how to resolve these tensions, few had completely accepted the liberalism that Berns claims informed their vision of the national government. Commitment to individual rights is part of the legacy 
left us by the framers of the Constitution. But if we are to take the framers seriously, we must also recognize that the founding generation did not completely break with the past, and that notions of communitarianism, of civic obligation and civic participation are part of their legacy as well. 